\title{
Anti-proliferative effect of pro-inflammatory cytokines in cultured $\beta$ cells is associated with extracellular signal- regulated kinase 1/2 pathway inhibition: protective role of glucagon-like peptide -1
}

\author{
M Blandino-Rosano, G Perez-Arana, J M Mellado-Gil, C Segundo* and M Aguilar-Diosdado* \\ Investigation Unit and Endocrinology and Nutrition Service, Puerta del Mar Hospital, Ana de Viya, 21, Cadiz 11009, Spain \\ (Correspondence should be addressed to C Segundo; Email: carmen.segundo.exts@juntadeandalucia.es; M Aguilar-Diosdado; Email: manuel.aguilar.sspa@juntadeandalucia.es) \\ ${ }^{*} \mathrm{C}$ Segundo and M Aguilar-Diosdado have participated equally in the study and the preparation of this manuscript
}

\begin{abstract}
Pancreatic $\beta$-cell homeostasis is a balance between programmed cell death (apoptosis) and regeneration. Although autoimmune diabetes mellitus type 1 (DM1) is the most-studied cause of $\beta$-cell mass loss by pro-inflammatory cytokineinduced apoptosis, influences of a pro-inflammatory environment on $\beta$-cell regenerative response have been poorly studied. In this study, we assess the anti-proliferative effect of pro-inflammatory cytokines and glucose concentration on rat pancreatic $\beta$ cells and the potential protective role of glucagon-like peptide (GLP-1). Apoptotic and proliferating islet cells were stained using the DeadEnd Fluorimetric TUNEL System and 5-bromo-2'-deoxyuridine label respectively, in the presence-absence of varying concentrations of glucose, pro-inflammatory cytokines, and GLP-1. The potential signaling pathways involved were evaluated by western blot. Considerable anti-proliferative effects of pro-inflammatory cytokines interleukin (IL)-1 $\beta$, interferon (IFN)- $\gamma$, and tumour necrosis factor- $\alpha$ (TNF- $\alpha$ ) were observed. The effects were synergistic and independent of glucose concentration, and appeared to be mediated by the inhibition of extracellular signal-regulated kinase 1/2 (ERK1/2) activation, the signaling pathway involved in $\beta$-cell replication. GLP-1 completely reversed the cytokine-induced inhibition of ERK phosphorylation and increased $\beta$-cell proliferation threefold in cytokine-treated cultures. While pro-inflammatory cytokines reduced islet cell ERK $1 / 2$ activation and $\beta$-cell proliferation in pancreatic islet culture, GLP-1 was capable of reversing this effect. These data suggest a possible pharmacological application of GLP-1 in the treatment of early stage DM1, to prevent the loss of pancreatic $\beta$ cells as well as to delay the development of overt diabetes.
\end{abstract}

Journal of Molecular Endocrinology (2008) 41, 35-44

\section{Introduction}

Autoimmune diabetes mellitus type 1 (DM1) is due to a selective death of pancreatic islet $\beta$ cells, mainly by apoptosis (Castano \& Eisenbarth 1990). Pro-inflammatory cytokines such as IL-1 $\beta$, alone or in combination with IFN- $\gamma$ and tumour necrosis factor- $\alpha$ (TNF- $\alpha)$, inhibit the glucose-induced insulin secretion and play an important role in $\beta$-cell damage (Andersen et al. 1994, Maedler et al. 2002).

$\beta$-cell homeostasis appears to be a balance between death and regeneration such that pancreatic $\beta$-cell mass remains constant. This is in agreement with the earlier studies that reported a basal replication rate in murine and human systems (Finegood et al. 1995, Butler et al. 2003, Teta et al. 2005). In addition, in some situations such as pregnancy or weight gain, $\beta$-cell mass must rise to adapt to a greater insulin demand (Sorenson \& Brelje 1997, Montanya et al. 2000). Replication and neogenesis processes appear to participate in this homeostasis. Recent studies have provided support for a significant neogenesis in humans (Bonner-Weir et al. 2000, Butler et al. 2003, Xu et al. 2008), and $\beta$-cell selfduplication has been described as the main form for $\beta$-cell mass increase in adult mice (Dor et al. 2004). There are several growth factors that play important roles in the regulation of the $\beta$-cell cycle. These include hepatocyte growth factor, insulin-like growth factors, and glucagon-like peptide-1 (GLP-1). All of these are capable of triggering proliferation signals, such as extracellular signal-regulated kinase $1 / 2$ (ERK1/2), phosphoinositide-3 kinase (PI3-K), and protein kinase C (PKC) (Vasavada et al. 2006) as well as acting upon basic machinery controlling the cell cycle in $\beta$ cells. This machinery, which acts upon $\mathrm{G} 2 / \mathrm{M}$ and more importantly on G1/S checkpoints, includes elements such as $\mathrm{pRb}$ (protein defective in human retinoblastoma), some cyclins, and cyclin-dependent kinases (For an extensive review see Cozar-Castellano et al. 2006).

Some pathological situations produce a loss of $\beta$ cells and result in an induction of compensatory responses via proliferation and/or neogenesis; partial pancreatectomy 
in rats results in a loss of $\beta$-cell differentiation (Jonas $e$ t al. 1999, Laybutt et al. 2001) and diet-inducing hyperglycemia has been shown to be associated with a transient proliferative response (Donath et al. 1999). However, no increased $\beta$-cell proliferation has been observed associated with the recent onset of DM1 in humans (Butler et al. 2007).

One of the common characteristics of pancreatic injury with inflammatory infiltration is the production of pro-inflammatory cytokines such as IL- $1 \beta$, IFN- $\gamma$, and TNF- $\alpha$, which have been shown to inhibit proliferation in certain experimental models (Dai et al. 2003, Song et al. 2005, Tellez et al. 2005).

GLP-1 and its analogs have beneficial effects on $\beta$-cell proliferation. GLP-1 induces islet cell regeneration following partial pancreatectomy (Xu et al. 1999, De Leon et al. 2003) and prevents diabetes by apoptosis inhibition (Wang \& Brubaker 2002). In vitro and ex vivo studies using GLP-1, or its receptor agonist exendin-4, have demonstrated that several signaling pathways are implicated in the proliferative action on $\beta$ cells. GLP-1 activates PI3K-Akt (Buteau et al. 2003, Wang et al. 2004) and protein kinase A (PKA) via increased cAMP levels (Briaud et al. 2003, Park et al. 2006). PKA, in addition to exerting an inhibitory action on the ERK pathway, can activate ERK by the alternative Rap-1 $>$ B-Raf $>$ MEK1 pathway (Pearson et al. 2001). An activation of the ERK1/2 pathway in response to glucose and GLP-1 has been described in human islet cells (Trumper et al. 2005).

Since $\beta$-cell mass is greatly reduced at the onset of DM1, it is crucial to know the early events occurring just before the disease is established and the influence of the pancreatic milieu on the capacity of islet cells to maintain a balance between apoptotic death and regeneration. In the present study, we evaluated the anti-proliferative effect of pro-inflammatory cytokines on $\beta$ cells and provide initial evidence of ERK1/2 signaling inhibition as one of the mechanisms underlying this effect. The capacity of GLP-1 to reverse this process could extend therapeutic perspectives of analogs of this compound for use in the preventive treatment of DM1.

\section{Materials and methods}

\section{Isolation and culture of rat islets}

All animal procedures were performed with the approval of the Animal Ethical Use and Care Committee of the Cádiz University School of Medicine (Cádiz, Spain). Pancreatic islets were isolated from adult male Wistar rats as described previously (McDaniel et al. 1983). Isolated islets were cultured in RPMI medium (SigmaAldrich) supplemented with $2 \mathrm{mM}$ L-glutamine (Gibco Invitrogen), $100 \mathrm{U} / \mathrm{ml}$ penicillin, and $100 \mu \mathrm{g} / \mathrm{ml}$ streptomycin (Pen-Strep; Bio-Whittaker Europe,
Verviers, Belgium). Fetal bovine serum (10\%) (FBS, Gibco Invitrogen) or albumin from bovine serum (5\%) (BSA, Sigma-Aldrich) were used for supplementing the cultures. Glucose concentration used in proliferation time-course assays was $5.5 \mathrm{mM}$ and, in the doseresponse experiments, $5 \cdot 5,7,11,17$, and $24.4 \mathrm{mM}$ glucose concentrations were used. Pro-inflammatory cytokines (PeproTech EC Ltd, London, UK) used in the experiments were recombinant human IL-1 $\beta$ $(50 \mathrm{U} / \mathrm{ml})$, recombinant rat IFN- $\gamma(1000 \mathrm{U} / \mathrm{ml})$, and recombinant rat TNF- $\alpha(1000 \mathrm{U} / \mathrm{ml})$. These concentrations were selected as being appropriate, based on the results of previous published studies (Eizirik et al. 1994, Delaney et al. 1997, Hoorens \& Pipeleers 1999). In assays for phosphorylated ERK quantification, the islets were maintained for $12 \mathrm{~h}$ in the RPMI culture medium described above, and with $5.5 \mathrm{mM}$ glucose for stability following isolation. Subsequently, the islets were treated with cytokines or GLP-1 (30 nmol/l; a kind gift from Novo Nordisk A/S, Bagsværd, Denmark). After 15-min, 30-min, 60-min, and 48-h incubation, the islets were harvested, washed in cold PBS, pelleted, and the pellet resuspended in sample buffer.

\section{Proliferation assays}

Proliferating cells were detected using 5-bromo-2'deoxyuridine $5 \mu \mathrm{mol} / 1$ (BrdU) label (Sigma-Aldrich), which was added to the cultures from the start of the assay together with, when appropriate, the cytokines being tested. Following the appropriate culture duration, the islets were recovered and incubated for $15 \mathrm{~min}$ with trypsin-EDTA $(0 \cdot 25 \%$ trypsin, 1 mM EDTA) in Hanks' balanced salt solution without $\mathrm{Ca}^{2+}$ and $\mathrm{Mg}^{2+}$ (Gibco Invitrogen) at $37^{\circ} \mathrm{C}$, and the islets were gently dispersed. After washing with PBS, the cells were cytospun onto polyL-lysine-coated slides and fixed in $4 \%$ methanol-free formaldehyde. The slides were immunostained using monoclonal mouse anti-bromodeoxyuridine (Dako Cytomation, Denmark) and polyclonal guinea pig anti-insulin (Sigma-Aldrich) antibodies, according to the manufacturer's instructions. The cells were permeabilized by incubation for 30 min with $0 \cdot 1 \%$ Triton-X100 in PBS and washed twice with $100 \mathrm{mM}$ glycine buffer containing $0 \cdot 1 \%$ Triton-X100 and 3\% BSA. The cells were then treated with $\mathrm{HCl}$ (2 M) in PBS for 30 min, neutralized with borax/borate buffer $(0 \cdot 1 \mathrm{M}, \mathrm{pH} 8 \cdot 9)$ for $30 \mathrm{~min}$, washed, and incubated overnight at $4{ }^{\circ} \mathrm{C}$ with anti-bromodeoxyuridine and anti-insulin antibodies. The stained cells were revealed using anti-mouse $\operatorname{IgG}$ (alexa-546 conjugated) and anti-guinea pig IgG (alexa-488 conjugated) antibodies (Molecular Probes Inc.; Eugene, OR, USA). The cell nuclei were stained with $4^{\prime}$-6-diamidino-2phenylindole (DAPI). To determine the proliferating fraction, total and insulin-positive/BrdU-positive cells were analyzed using a fluorescence microscope in 
randomized conditions by a single investigator (M B-R) and, for statistical purposes, the percentage of positive cells was calculated for each incubation condition.

\section{Apoptosis and proliferation double staining}

The pancreatic islets were cultured for $48 \mathrm{~h}$ and BrdU was added to the cultures from the start of the assay together with the cytokines, when appropriate. Then, islet cells were dispersed, cytospun, and fixed, as described above. Apoptotic and proliferating islet cells were stained simultaneously using the DeadEnd Fluorimetric TUNEL System (Promega) according to the manufacturer's instructions and then treated with $\mathrm{HCl}(2 \mathrm{M})$ in $\mathrm{PBS}$ for $30 \mathrm{~min}$, neutralized with borax/borate buffer $(0.1 \mathrm{M}, \mathrm{pH} 8.9)$ for $30 \mathrm{~min}$, washed, and incubated overnight at $4{ }^{\circ} \mathrm{C}$ with antibromodeoxyuridine. BrdU stain uptake was revealed using anti-mouse IgG antibody (alexa-546 conjugated). The cell nuclei were stained with DAPI. Total, TUNELpositive (green), BrdU-positive (red), and doublestained cells were analyzed using a fluorescence microscope in randomized conditions by a single investigator (M B-R) and, for statistical purposes, the percentage of positive cells was calculated for each incubation condition.

\section{Western blot}

Equivalent numbers of islets under the different experimental conditions described above were lysed in $60 \mathrm{mM}$ Tris-HCl buffer ( $\mathrm{pH} 6-8$ ), containing $2 \%$ SDS, $10 \%$ glycerol, $0 \cdot 1 \%$ bromophenol blue, and $5 \%$ $\beta$-mercaptoethanol. Lysed islets were boiled for $5 \mathrm{~min}$ and then loaded and electrophoresed on 10-12\% SDSPAGE. The proteins were transfer-blotted on to polyvinylidene fluoride membrane. The blot was then incubated in blocking buffer $(5 \%$ non-fat milk in $10 \mathrm{mM}$ Tris- $\mathrm{HCl}, 1 \cdot 15 \mathrm{M} \mathrm{NaCl}$, and $0 \cdot 1 \%$ Tween-20) for $1 \mathrm{~h}$ at room temperature. The blots were then incubated with rabbit polyclonal antibody against phospho-ERK1/2 (Cell Signaling, Beverly, MA, USA) overnight according to the manufacturer's instructions, followed by incubation with peroxidase-conjugated anti-rabbit IgG for $1 \mathrm{~h}$ at room temperature. Phosphorylated ERK1/2 bands were revealed using LiteAblot (EuroClone, Italy) and quantified by Quantity One software Version Upgrade (Bio-Rad). The membranes were then stripped in Restore western blot stripping buffer (Pierce, Rockford, IL, USA), washed with Tween-TBS, and immunoblotted using rabbit polyclonal antibody against ERK1/2 (Cell Signaling). ERK1/2 bands were quantified and the ratios between total and phosphorylated ERK1/2 were calculated.

\section{Statistical analyses}

Results are presented as means \pm s.E.M. of at least three independent and separate experiments. Statistical comparisons were performed by either Mann-Whitney test or ANOVA. $P<0.05$ were considered statistically significant.

\section{Results}

\section{Pro-inflammatory cytokines act synergistically, and in a glucose-independent manner, in suppressing cultured $\beta$-cell proliferation}

Islets were cultured for 24,48 , and $72 \mathrm{~h}$ with $5.5 \mathrm{mM}$ glucose and BrdU-positive $\beta$ cells were quantified. At $72 \mathrm{~h}$, the percentage of proliferating $\beta$ cells reached a tenfold increase with respect to the 24-h value, and the addition of IL- $1 \beta+\mathrm{TNF}-\alpha+\mathrm{IFN}-\gamma$ to the culture reduced the number of positive BrdU-positive $\beta$ cells (Fig. 1A). Cytokineinduced apoptosis and the proliferating cells undergoing apoptosis were studied at 48-h culture using doublestaining TUNEL/BrdU. The cytokines induced apoptosis in islet cells, but there was no apoptosis increase in proliferating islet cells; the double-staining fraction remaining near-undetectable in control cultures and in cytokine-supplemented cultures (Fig. 1B).

The effect of pro-inflammatory cytokines, alone or in combination, was tested following 48-h culture. Individual cytokines had no significant effect on $\beta$-cell proliferation when incubated alone. When incubated in pairs, IL- $1 \beta+\mathrm{TNF}-\alpha$ and IL- $1 \beta+$ IFN- $\gamma$ had significant intermediate effects. Only TNF- $\alpha+\mathrm{IFN}-\gamma$ acted similarly to that of all cytokines in combination (Fig. 2).

To investigate whether the anti-proliferative effect of cytokines depended on glucose concentration, pancreatic islets were cultured at 5.5, 7, 11, 17, and $24.4 \mathrm{mM}$ glucose with and without IL-1 $\beta+\mathrm{TNF}-\alpha+$ IFN- $\gamma$. Although in the absence of cytokines BrdUpositive $\beta$-cell number appeared to increase at $7 \cdot 7 \mathrm{mM}$ glucose, the difference did not reach statistical significance at 48 -h culture. The percentage of $\beta$-cell proliferation in the presence of cytokines was the same at all the different glucose concentrations, indicating that this effect was independent of glucose levels (Fig. 3).

\section{ERK1/2 activation is inhibited by pro-inflammatory cytokines}

Phospho-ERK1/2 was quantified in the islet cells following exposure to cytokines for 15, 30, and $60 \mathrm{~min}$. The values were compared with control cultures without cytokines. Phospho-ERK1/2 expression in the islet cells was reduced along the time course of exposure to cytokines, reaching a maximum level of inhibition at 
$30 \mathrm{~min}$, which was maintained up to $60 \mathrm{~min}$ (Fig. 4). No changes were observed in the ERK expression over the time course of culture prior to the assay, probably due to isolation procedures used (data not shown).

A
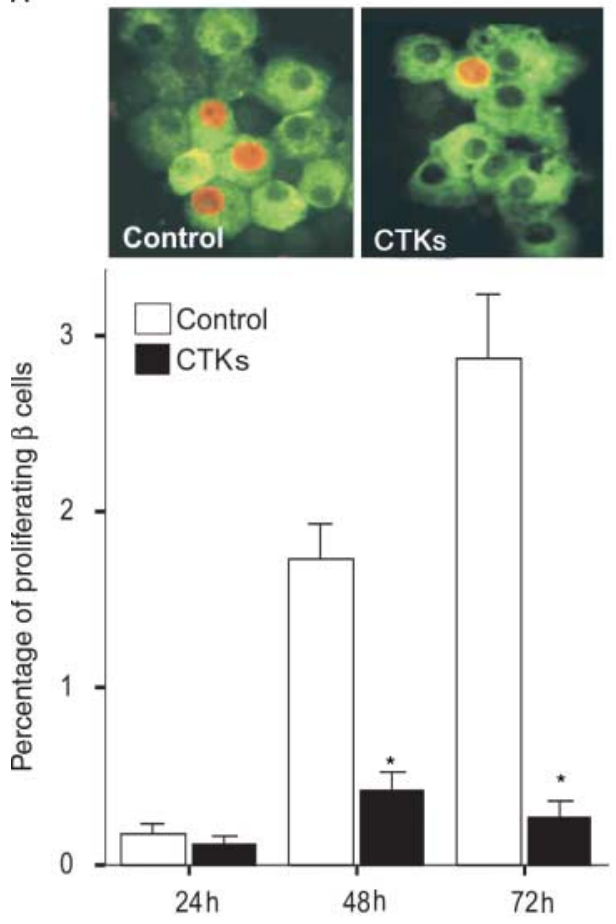

B
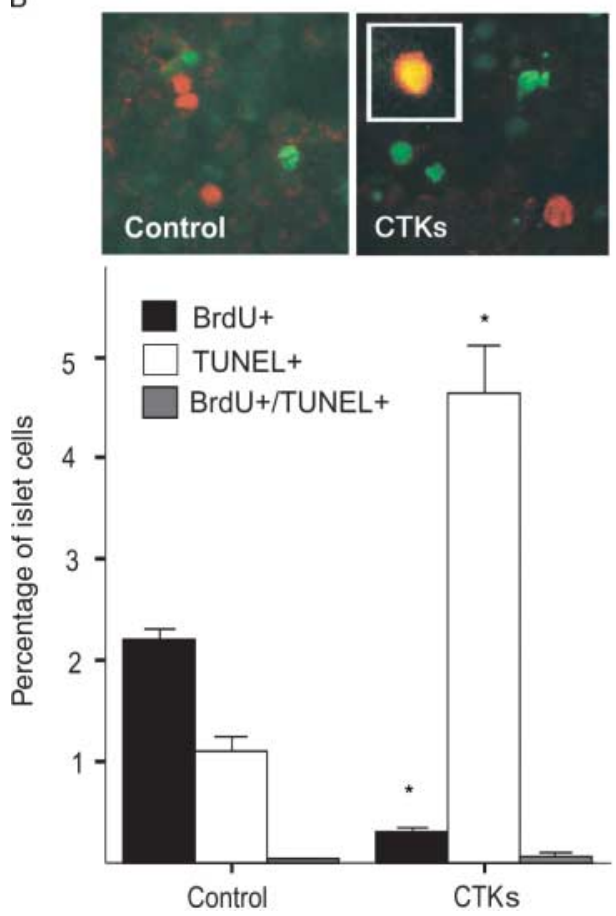

\section{ERK1/2 inhibition has parallel effects on $\beta$-cell proliferation as pro-inflammatory cytokines}

MEK1 inhibitor PD98059 was used to test the role of ERK1 $/ 2$ in cultured $\beta$ cells, and to explore the effect of cytokines on the ERK1/2 expression and $\beta$-cell proliferation. PD98059 alone as well as PD98059 plus cytokines induced between $2 \cdot 6$ - and 5 -fold decreases in $\beta$-cell proliferation. The rate was similar to that induced by cytokines $(4 \cdot 2$-fold relative to control) in 48 -h islet cultures (Fig. 5).

\section{GLP-1 has a protective role against anti-proliferative effects of cytokines}

To test the effect of a recognized $\beta$-cell ERK activator, as GLP-1, in the anti-proliferative action of cytokines, $\beta$-cell cultures were performed with both, cytokines and GLP-1 $(30 \mathrm{nmol} / \mathrm{l})$. Overall effects of GLP-1 and cytokines were evaluated in terms of ERK activation and $\beta$-cell proliferation. For the control of GLP-1 action in the absence of growth factors, a culture supplemented with 5\% BSA instead of FBS was performed. In BSA-supplemented cultures, ERK activation was induced by GLP-1 thus confirming the capacity to activate ERK pathway in $\beta$ cells (Fig. 6A). However, in FBS-supplemented cultures, high level of ERK activation without any effect of GLP-1 was observed. When cytokines were added to the culture, an ERK phosphorylation inhibition was observed after $30 \mathrm{~min}$, which was completely reversed by GLP-1 (Fig. 6B). Nevertheless, although the addition of GLP-1 increased $\beta$-cell proliferation by threefold compared with cytokine-treated 48-h cultures (Fig. 7), this effect did not imply a total recovery to previous proliferation rates. A concentration of $60 \mathrm{nmol} / 1 \mathrm{did}$ not increase GLP-1 effect on $\beta$-cell proliferation under these conditions (data not shown).

Figure 1 Effect of pro-inflammatory cytokines on cultured $\beta$-cell proliferation. (A) Rat islets were cultured for 24,48 , and $72 \mathrm{~h}$ in $5.5 \mathrm{mM}$ glucose medium alone (control, white bars) or in combination with IL-1 $\beta(50 \mathrm{U} / \mathrm{ml})+\mathrm{IFN}-\gamma(1000 \mathrm{U} / \mathrm{ml})+\mathrm{TNF}-\alpha$ $(1000 \mathrm{U} / \mathrm{ml})(C T K s$, black bars) and stained with BrdU during the whole course of the culture period. Upper panels show a representative image of insulin- (green) and BrdU (red)-stained islet cells after 48-h culture. Bar diagram expresses results as means \pm S.E.M. of percentage of accumulated BrdU-positive/insulin-positive cells over the culture period relative to insulin-positive cells, in a minimum of five experiments. (B) Rat islets were cultured for $48 \mathrm{~h}$ in $5.5 \mathrm{mM}$ glucose medium, alone or with cytokines and stained with BrdU during the whole course of the culture period. BrdU-positive (black bars), TUNEL-positive (white bars), and double-stained BrdU-positive/TUNEL-positive (grey bars) cells were quantified. Upper panels show representative images of TUNEL (green), BrdU-(red), and BrdU-positive/TUNELpositive (yellow, in square) stained islet cells. Graph expresses results as means \pm S.E.M. of the percentages of three populations of cells in five experiments and refers to total cell number. ${ }^{\star} P<0.05$ treated versus control without cytokines. 


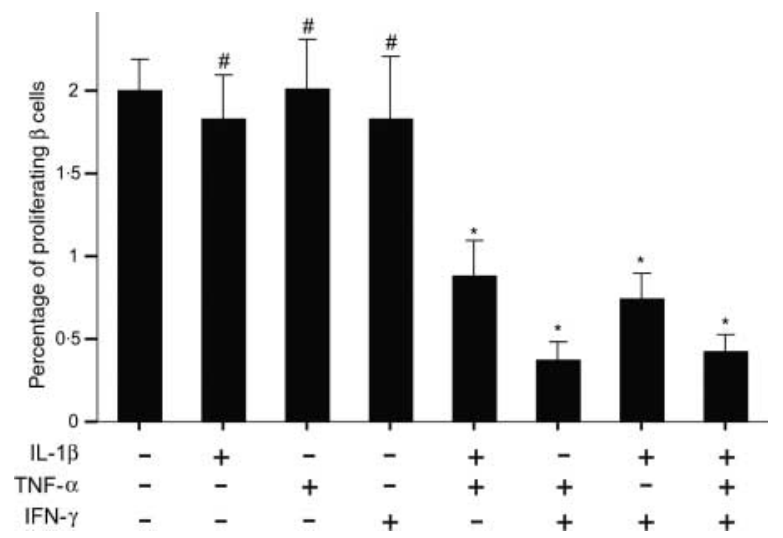

Figure 2 Effect of pro-inflammatory cytokines alone or in combination. Rat islets were cultured for $48 \mathrm{~h}$ in $5.5 \mathrm{mM}$ glucose medium, alone or in combination with IL-1 $\beta$ (50 U/ml), IFN- $\gamma$ $(1000 \mathrm{U} / \mathrm{ml})$, TNF- $\alpha(1000 \mathrm{U} / \mathrm{ml}), \mathrm{IL}-1 \beta+\mathrm{IFN}-\gamma, \mathrm{IFN}-\gamma+\mathrm{TNF}-\alpha$, IL- $1 \beta+$ TNF- $\alpha$, and IL- $1 \beta+$ IFN- $\gamma+$ TNF- $\alpha$ and stained with BrdU during the whole course of the culture period. Results are expressed as means \pm S.E.M. of the percentage of combined $\mathrm{BrdU} /$ insulin-positive cells relative to insulin-positive cells in a minimum of five experiments. ${ }^{*} P<0.05$ treated versus islets control without cytokines; ${ }^{\#} P<0.05$ treated versus islets exposed to IL-1 $\beta+$ IFN- $\gamma+$ TNF- $\alpha$.

Signaling pathway effects of GLP-1 were tested using H89 $(10 \mu \mathrm{mol} / \mathrm{l})$ and PD98059 $(50 \mu \mathrm{mol} / \mathrm{l})$, inhibitors of PKA and ERK1/2 pathways respectively. The addition of H89 barely alters the recovery of the proliferation

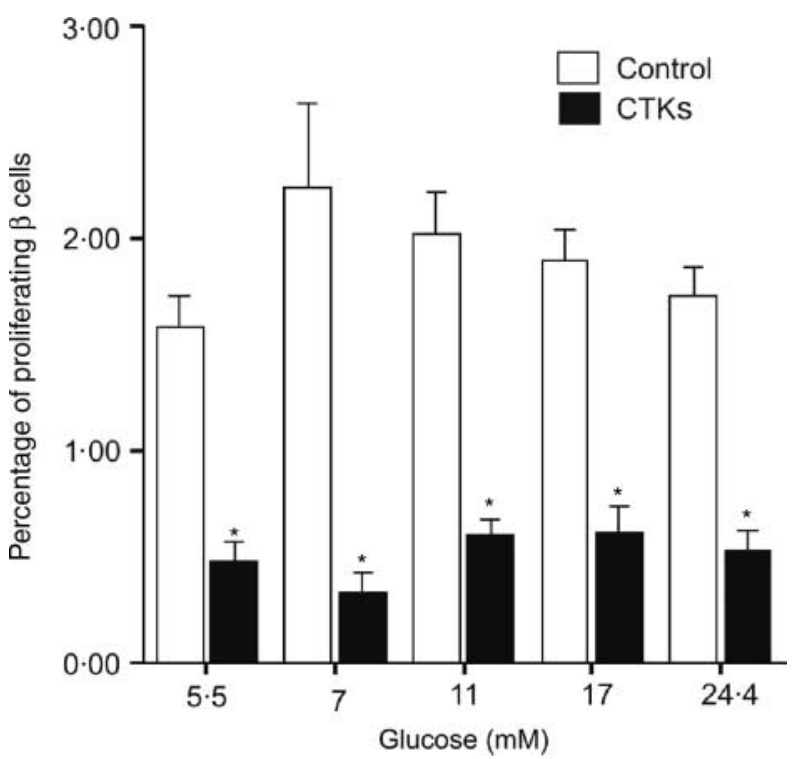

Figure 3 Role of glucose concentration in the anti-proliferative effect of cytokines. Rat islets were cultured for $48 \mathrm{~h}$ in $5 \cdot 5,7,11$, and $24.4 \mathrm{mM}$ glucose medium, alone (control, white bars) or in combination with IL-1 $\beta(50 \mathrm{U} / \mathrm{ml})+\mathrm{IFN}-\gamma(1000 \mathrm{U} / \mathrm{ml})+\mathrm{TNF}-\alpha$ $(1000 \mathrm{U} / \mathrm{ml})(\mathrm{CTKs}$, black bars) and stained with BrdU during the whole course of the culture period. Results are expressed as means \pm S.E.M. of the percentage of combined BrdU/insulinpositive cells relative to insulin-positive cells in a minimum of five experiments. ${ }^{*} P<0.05$ treated versus control without cytokines.

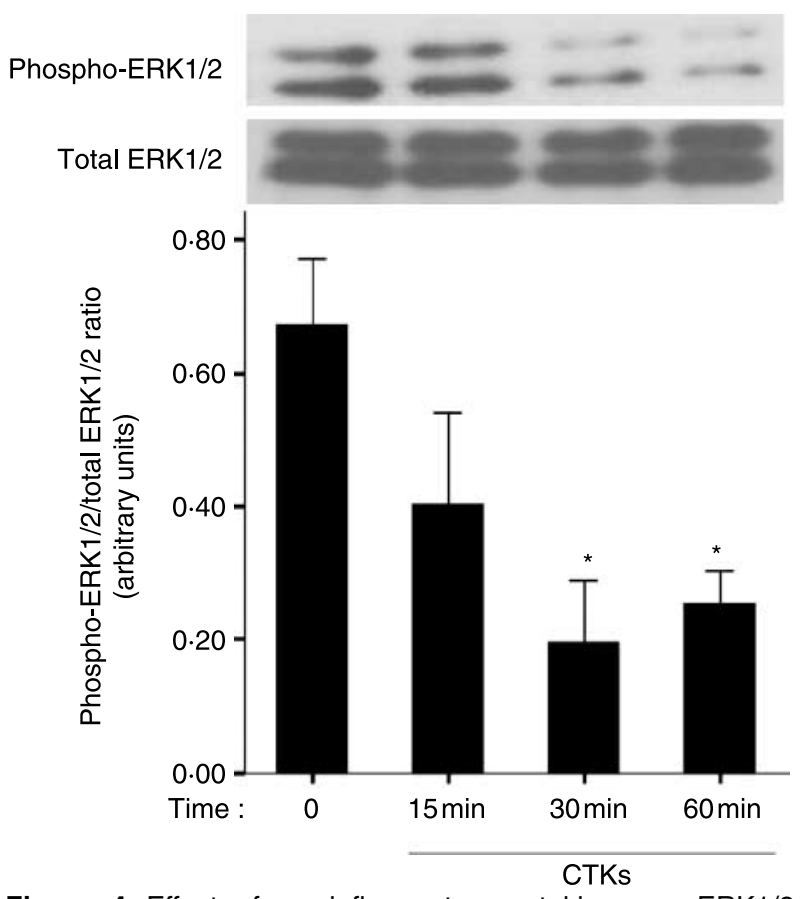

Figure 4 Effect of pro-inflammatory cytokines on ERK1/2 activation. Rat islets were cultured for $12 \mathrm{~h}$ and had additional $\mathrm{IL}-1 \beta(50 \mathrm{U} / \mathrm{ml})+\mathrm{IFN}-\gamma(1000 \mathrm{U} / \mathrm{ml})+\mathrm{TNF}-\alpha(1000 \mathrm{U} / \mathrm{ml})(\mathrm{CTKs})$ for $15 \mathrm{~min}, 30 \mathrm{~min}, 60 \mathrm{~min}$, and $48 \mathrm{~h}$, and had levels of ERK1/2 phosphorylation assayed. Upper panel is a representative image of phospho-ERK $1 / 2$ and total ERK1/2 immunoblotting. Results are expressed as means \pm S.E.M. of phospho-ERK $1 / 2$ to totalERK $1 / 2$ ratio measured by densitometry in a minimum of five experiments. Units on the $y$-axis are arbitrary. ${ }^{*} P<0.05$ treated versus control without cytokines.

induced by GLP-1 in cultures treated with cytokines. On the other hand, PD98059 abolishes GLP-1-mediated recovery of proliferation in cytokine-treated islet cultures. This effect is clear, albeit proliferation values in PD98059-treated cultures are low due to the important role of the ERK1/2 signaling in $\beta$-cell replication (Fig. 8).

\section{Discussion}

Pro-inflammatory cytokines such as IL- $1 \beta$, IFN- $\gamma$, and TNF- $\alpha$ play essential roles in the pathogenesis of DM1. Many studies have focused on the apoptotic effects of cytokines, such as in the destruction of pancreatic $\beta$ cells. Cell culture assays have demonstrated significant antiproliferative action in immortalized cell lines ( $\mathrm{Li}$ et al. 2005) and in primary cultures, suggesting that proinflammatory cytokines may be involved in the loss of regenerative response when a damaging circumstance such as insulitis is present. In the present study, the rat pancreatic islets were cultured in $5.5 \mathrm{mM}$ glucose and $10 \%$ FCS-supplemented medium. Due, probably, to the 


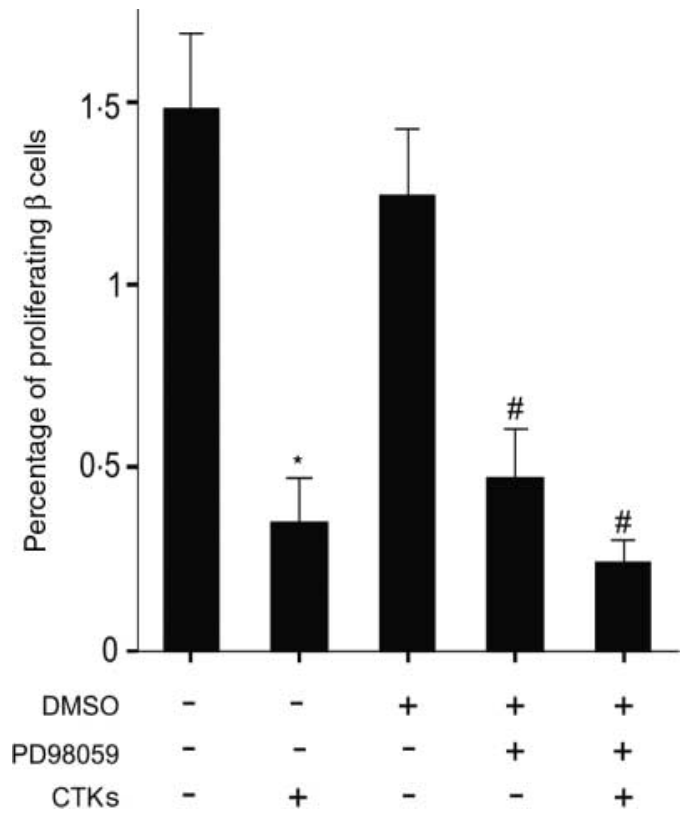

Figure 5 Effect of ERK1/2 signal pathway inhibition in islet $\beta$-cell proliferation. Rat islets were cultured for $48 \mathrm{~h}$ in $5.5 \mathrm{mM}$ glucose medium, alone or in combination with IL-1 $\beta(50 \mathrm{U} / \mathrm{ml})+\mathrm{IFN}-\gamma$ $(1000 \mathrm{U} / \mathrm{ml})+$ TNF- $\alpha(1000 \mathrm{U} / \mathrm{ml})(C T K s)$, PD98059, and PD98059 + CTKs, and stained with BrdU during the whole course of the culture period. A control with DMSO was performed for cultures containing PD98059 $(50 \mu \mathrm{M})$. Results are presented as means \pm S.E.M. of the percentage of combined BrdU/insulinpositive cells relative to insulin-positive cells in a minimum of five experiments. ${ }^{*} P<0.05$ treated versus control; ${ }^{\#} P<0.05$ treated versus control with DMSO.

impact of the isolation procedure, $\beta$ cells showed a low proliferation rate over the first $24 \mathrm{~h}$ and, subsequently, proliferative activity remained at a constant rate. Under these conditions, when cytokines were added to the culture, an anti-proliferative effect was observed. This effect is higher when the three-set cytokines (IL-1 $\beta$, IFN- $\gamma$, and TNF- $\alpha$ ) are added in combination, or when the combination was IFN- $\gamma+\mathrm{TNF}-\alpha$. These data are in contrast to a previous report in which the addition of IL-1 $\beta$ alone appeared to have a significant anti-proliferative effect (Tellez et al. 2005). This difference in outcome could have been related to the culture conditions and cytokine concentrations used (MelladoGil \& Aguilar-Diosdado 2005). We had used the set of three pro-inflammatory cytokines (IL- $1 \beta$, IFN- $\gamma$, and TNF- $\alpha$ ) to mimic the pancreatic milieu during the prediabetic stage. Observed loss of proliferative response could be due to cytokine-mediated apoptosis affecting, mainly, the replicating $\beta$ cells. To assess this possibility, we quantified the double TUNEL- and BrdU-positive cells. The double-stained cells were almost non-existent, and their numbers were not increased by the presence of cytokines. This suggests that replicating $\beta$ cells are not more susceptible to cytokine-mediated apoptosis, and
A

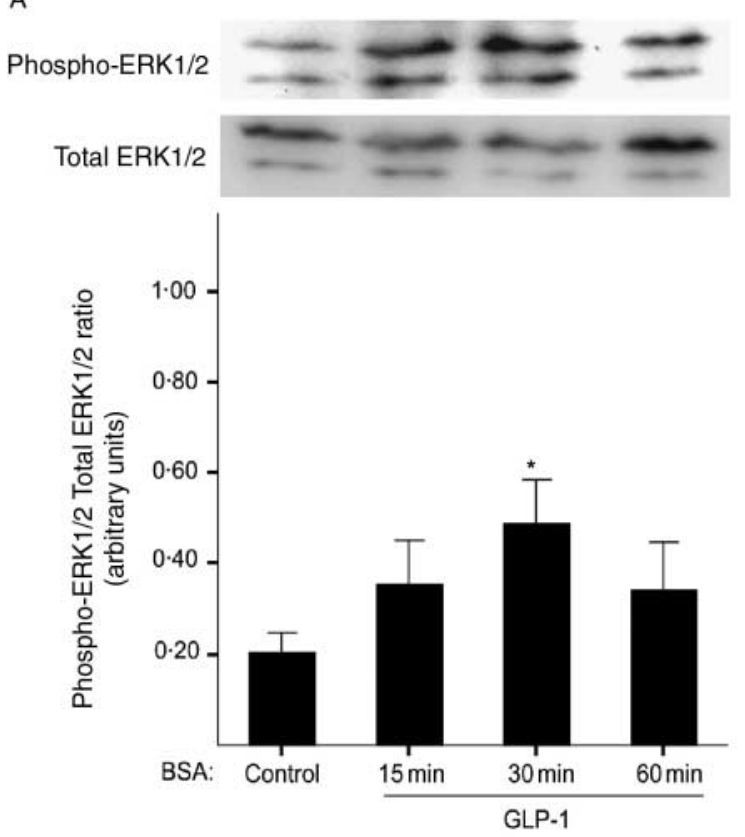

B
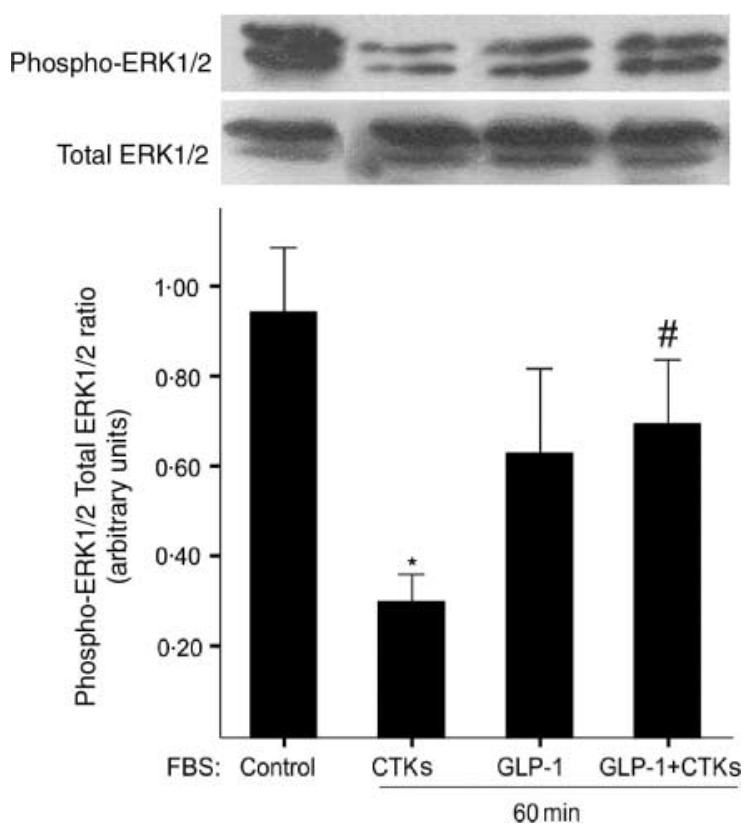

Figure 6 Effect of GLP-1 in cytokine-induced ERK1/2 inactivation. Rat islet cells pre-cultured for $12 \mathrm{~h}$ in culture medium supplemented with (A) $5 \%$ BSA or (B) $10 \%$ FBS were treated with GLP-1 $(30 \mathrm{nmol} / \mathrm{l})$ in the presence or absence of IL-1 $\beta(50 \mathrm{U} / \mathrm{ml})+\mathrm{IFN}-\gamma$ $(1000 \mathrm{U} / \mathrm{ml})+$ TNF- $\alpha(1000 \mathrm{U} / \mathrm{ml})($ CTKs $)$ for the indicated times. The levels of ERK $1 / 2$ phosphorylation were measured and compared with untreated control. Upper panel is a representative image of phospho-ERK1/2 and total ERK1/2 immunoblotting. Results are expressed as means \pm s.E.M. of phospho-ERK $1 / 2$ to total-ERK $1 / 2$ ratio measured by densitometry in a minimum of five experiments. Units on the $y$-axis are arbitrary. ${ }^{*} P<0.05$ treated versus control culture; ${ }^{\#} P<0.05$ treated versus CTKs. 


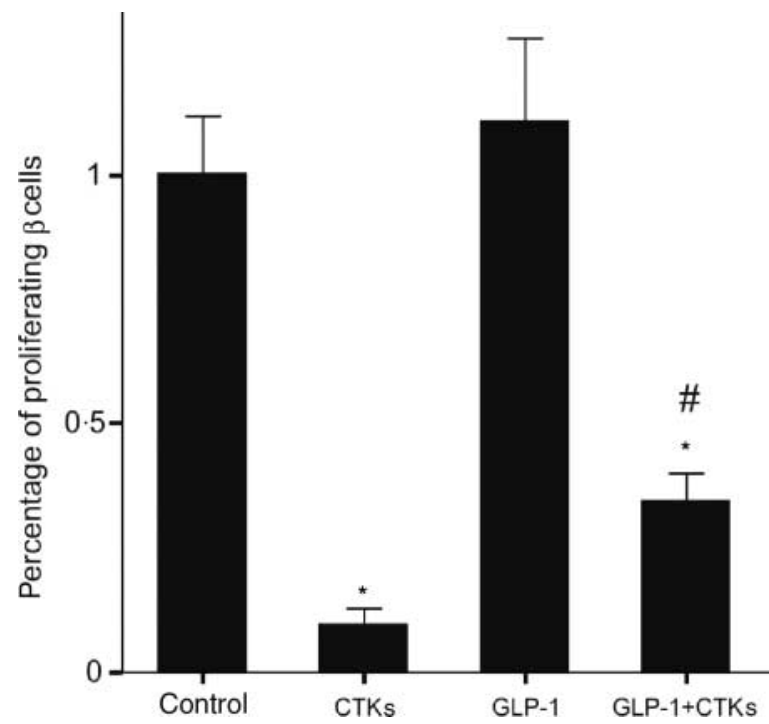

Figure 7 Effect of GLP-1 on $\beta$-cell anti-proliferative action of proinflammatory cytokines. Rat islets were cultured for $48 \mathrm{~h}$ in $5.5 \mathrm{mM}$ glucose medium, alone or in combination with IL-1 $\beta(50 \mathrm{U} / \mathrm{ml})+$ IFN- $\gamma(1000 \mathrm{U} / \mathrm{ml})+$ TNF- $\alpha(1000 \mathrm{U} / \mathrm{ml})(\mathrm{CTKs}), \mathrm{GLP}-1$, and GLP-1 $(15,30$, and $60 \mathrm{nmol} / \mathrm{l})+\mathrm{CTKs}$, and stained with BrdU during the whole course of the culture period. Proliferation was quantified in insulin-positive cells and expressed as means \pm S.E.M. of the percentage of combined BrdU/insulin-positive cells relative to insulin-positive cells in a minimum of five experiments. ${ }^{\star} P<0.05$ treated versus untreated control; ${ }^{\#} P<0.05$ treated versus CTKs.

that the anti-proliferative effect of cytokines on $\beta$ cells is due to an active process.

We found no changes in the anti-proliferative effect of cytokines when $\beta$ cells were cultured at different glucose concentrations in the culture medium. This independence of glucose concentration indicates that the cytokine anti-proliferative effect would be a relevant phenomenon from the earliest stages in the clinical evolution of the disease; especially when glycemia is within the normal range in the stages of subclinical diabetes. Conversely, the effect of cytokines in inducing apoptosis is increased at $24.4 \mathrm{mM}$, as previously reported by our group (Mellado-Gil \& Aguilar-Diosdado 2004). These results suggest that the cytokinemediated anti-proliferative events could be responsible for the $\beta$-cell mass loss from the beginning of insulitis, and that the apoptotic events would become more important at the same time that glucose levels increase.

ERK1/2, which belongs to the MAPK family, is a key factor in the control of survival, growth, differentiation, and transformation in many cell systems. In $\beta$ cells, ERK1/2 is activated in response to extracellular stimuli such as the glucose concentration, or other growth factors implicated in pancreatic tissue homeostasis (Vasavada et al. 2006). As well, ERK1/2 induction is mediated by $\beta$-cell integrins and extracellular matrix interaction (Hammar et al. 2004). We observed that, in islet culture, the pharmacological inhibition of ERK1/2 by PD98059 considerably reduces $\beta$-cell proliferation, demonstrating that ERK1/2 is a major pathway involved in $\beta$-cell proliferation. Previous studies in immortalized cell lines have reported an induction of the ERK1/2 pathway in response to pro-inflammatory cytokines, mainly IL-1 $\beta$ (Larsen et al. 1998, Maedler et al. 2004). By contrast, we found in $\beta$ cells from ex vivo cultured islets in the presence of optimal glucose and 10\% FCS, a basal level of ERK1/2 activation that was drastically inhibited by the IL-1 $\beta+$ IFN- $\gamma+$ TNF- $\alpha$ combination. The mechanisms by which pro-inflammatory cytokines inhibit ERK1/2 activation in $\beta$ cells are as yet unclear although inhibition has been shown to occur within $30 \mathrm{~min}$ and, as such, would indicate that non-transcriptional regulation could be involved. Loss of activated ERK1/2 in a short time period suggests that the cytokines' anti-proliferative effect is due to an active process and not due to consequences of apoptosis. Several routes of ERK1/2 phosphorylation-mediation could crosswalk with ERK pathways triggering its negative regulation in response to cytokines. Most of these trigger Raf-1, which in turn activates mitogen-activated protein kinase and ERK kinase 1 (MEK1), which will phosphorylate ERK1/2. Raf-1 may be phosphorylated in multiple sites and, depending on the site phosphorylated, will be positively or negatively regulated. Little is known regarding the molecular pathways involved in the negative regulation of Raf-1, and ERK1/2 has been suggested as being operative via a negative feed-back loop (Dougherty et al. 2005). Thus, p38 belonging to MAPK family is activated by pro-inflammatory cytokines and studies in immortalized cell lines have shown that an inhibitor of p38, SB203580, significantly enhances epidermal growth factor-induced ERK activation demonstrating a crosstalk between ERK and p38. The mechanism of this inhibition may be the p38-mediated activation of protein phosphatase 2A (pp2A) that inhibits the level of MEK phosphorylation. The cAMP/PKA/CREB pathway is activated by IFN- $\gamma$ and TNF- $\alpha$ and may be also involved in the negative regulation of ERK pathway. The proposed mechanism for PKA-inducing ERK inhibition involves direct phosphorylation of c-Raf by PKA, which blocks c-Raf interaction with Ras (Dumaz \& Marais 2005). PKB/Akt is another candidate implicated in negative regulation of the ERK pathway by either phosphorylating or forming a complex with Raf. (Rommel et al. 1999, Zimmermann \& Moelling 1999, Chaudhary et al. 2000). Although PKB/Akt pathway can be potentially activated by pro-inflammatory cytokines, there is evidence from immortalized $\beta$-cell lines that $\mathrm{PKB} /$ Akt activation is also abrogated in a pro-inflammatory cytokine-dependent manner $(\mathrm{Li}$ et al. 2005). Moreover, AMP-activated protein kinase, a sensor of cellular energy charge that has been shown recently to be involved in pro-inflammatory cytokines $\beta$-cell damage (Richards et al. 2005, Riboulet-Chavey et al. 2008)), may have also an anti-proliferative effect (Jones et al. 2005, Motoshima et al. 2006). 


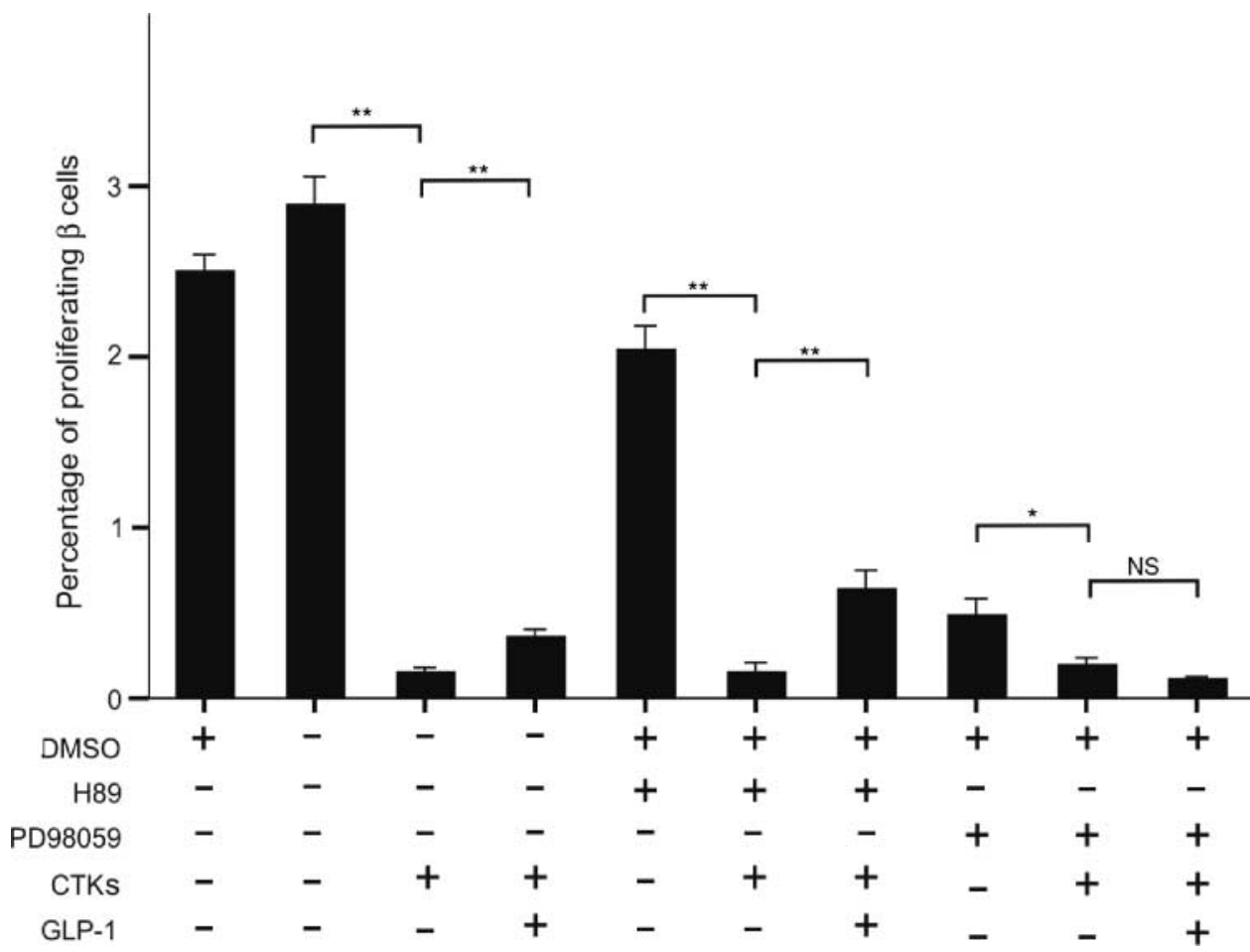

Figure $8 \mathrm{Effect}$ of signaling pathway inhibitors on GLP-1 action. Rat islets were cultured for $48 \mathrm{~h}$ in $5.5 \mathrm{mM}$ glucose medium, alone or in combination with IL-1 $\beta(50 \mathrm{U} / \mathrm{ml})+\mathrm{IFN}-\gamma(1000 \mathrm{U} / \mathrm{ml})+\mathrm{TNF}-\alpha(1000 \mathrm{U} / \mathrm{ml})$

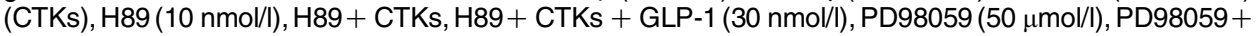
CTKs, and PD98059+ CTKs + GLP-1, and stained with BrdU during the whole course of the culture period. A control with DMSO was performed for cultures containing $\mathrm{H} 89$ and PD98059. Results are represented as means \pm S.E.M. of the percentage of combined BrdU/insulin-positive cells relative to insulin positive cells in a minimum of five experiments. ${ }^{*} P \leq 0 \cdot 05,{ }^{* \star} P<0 \cdot 01$, NS: not significant.

Since GLP-1 has, among its effects, the ability to increase $\beta$-cell proliferative response in most systems studied, we tested whether GLP-1 could modify cytokinemediated inhibition of ERK1/2 phosphorylation or the effect on $\beta$-cell proliferation. In the absence of cytokines, we observed no significant effect of GLP-1 on ERK activation. In addition, GLP-1 did not modify $\beta$-cell proliferation under these conditions. However, in $\beta$-cell cultures in which FCS is replaced by BSA, a positive effect of GLP-1 on ERK activation was observed. The explanation for this finding could be that fetal calf serum and glucose in the culture medium are able, of themselves, to trigger the highest signals for proliferation.

Nevertheless, the GLP-1 effect was quite different in the presence of cytokines. ERK1/2 activation was totally recovered and $\beta$-cell proliferation rate increased by threefold, albeit still remaining lower than the control value. This lack of a complete recovery of proliferation, despite complete activation of ERK1/2, could be due to multiple signaling pathways triggered by GLP-1, which may act negatively on $\beta$-cell proliferation (Zimmermann \& Moelling 1999, Dhillon et al. 2002). Although GLP-1 and glucose activate the ERK1/2 by a cAMP-PKAdependent pathway in immortalized $\beta$ cells (Briaud et al. 2003), we found that the GLP-1 had a protective effect through reversed cytokine-induced ERK1/2 phosphorylation inhibition. The PKA inhibitor, H89, did not have an effect on GLP-1 protective action due, probably, to a different system (ex vivo culture), that used a culture medium with several growth factors contained in the fetal calf serum, and the possibility of cAMP induced ERK1/2 activation in a PKA-independent manner. In this sense, the role of cAMP-regulated guanine nucleotide exchange factor (Epac) in GLP-1 receptor-mediated signal transduction in $\beta$ cells, and Epac-dependent, PKA-independent ERK1/2 activation in response to cAMP has been described (Busca et al. 2000, Lin et al. 2003, Holz 2004, Johnson-Farley et al. 2005, Fang \& Olah 2007). On the other hand, treatment with PD98059, which blocks ERK1/2 pathway by inhibiting MAP kinase (MEK), abrogates the effect of GLP-1 on cytokine-treated cultures. This feature confirms that restoration of ERK activation is important in the mechanism of GLP-1mediated proliferation recovery and that a more detailed knowledge of these pathways would be of considerable interest in enabling the pharmacological modulation of $\beta$-cell response to GLP-1, in the presence of cytokines. 
The $\beta$-cell proliferation recovery mediated by GLP-1 in the presence of cytokines is noteworthy because, in maintaining cell proliferation rate during the subclinical diabetes phase, it may be possible to avoid or delay the loss of pancreatic $\beta$ cells leading to overt DM1. In this sense, earlier reports showed that an analog of GLP-1 synergistically augments the remission-inducing effect of a polyclonal anti-T-cell antibody on overtly diabetic NOD mice (Ogawa et al. 2004) and may enhance $\beta$-cell mass in a streptozotocin-induced diabetes model (Soltani et al. 2007). Further details of potential signaling pathways implicated in $\beta$-cell proliferation, which are inactivated by pro-inflammatory cytokines and regulated by GLP-1, will enable the selection of more specific drugs which, administered alone or in combination with GLP-1, would restore $\beta$-cell proliferation in the presence of cytokines without causing ablation of the immune system.

In conclusion, our data suggest that, in autoimmune cytokine-mediated diabetes, the inhibition of $\beta$-cell proliferation causes loss of $\beta$-cell mass which, together with the apoptosis phenomenon, leads to a massive destruction and a non-regeneration of pancreatic $\beta$ cells. We describe an important non-glucose-dependent anti-proliferative effect of pro-inflammatory cytokines due, especially, to synergistic action of IFN $\gamma$ and TNF- $\alpha$ and have shown that an inhibition of the ERK1/2 pathway mediated by cytokines could, at least in part, be the mechanism involved. The capacity of GLP-1 to reverse the anti-proliferative effect of cytokines in $\beta$ cells suggests that its use in early stages of autoimmune diabetes would protect $\beta$-cell proliferation, and could be potentially effective in preventing $\beta$-cell mass loss and clinical diabetes.

\section{Acknowledgements}

We thank the Animal Production and Research Service of Cádiz University for technical support. Editorial assistance was by Dr Peter R Turner. This study was financed, in part, by grants from the Diabetes Group Network of the Spanish Ministry of Health (FIS G03/212; FIS PI052164) and the Andalusia Department of Health (CTS-368). The authors declare that there is no conflict of interest that would prejudice the impartiality of this scientific work.

\section{References}

Andersen HU, Jorgensen KH, Egeberg J, Mandrup-Poulsen T \& NerupJ 1994 Nicotinamide prevents interleukin-1 effects on accumulated insulin release and nitric oxide production in rat islets of Langerhans. Diabetes 43 770-777.

Bonner-Weir S, Taneja M, Weir GC, Tatarkiewicz K, Song KH, Sharma A \& O'Neil JJ 2000 In vitro cultivation of human islets from expanded ductal tissue. PNAS 97 7999-8004.
Briaud I, Lingohr MK, Dickson LM, Wrede CE \& Rhodes CJ 2003 Differential activation mechanisms of Erk-1/2 and p70(S6K) by glucose in pancreatic beta-cells. Diabetes 52 974-983.

Busca R, Abbe P, Mantoux F, Aberdam E, Peyssonnaux C, Eychene A, Ortonne JP \& Ballotti R 2000 Ras mediates the cAMP-dependent activation of extracellular signal-regulated kinases (ERKs) in melanocytes. EMBO Journal 19 2900-2910.

Buteau J, Foisy S, Joly E \& Prentki M 2003 Glucagon-like peptide 1 induces pancreatic $\beta$-cell proliferation via transactivation of the epidermal growth factor receptor. Diabetes 52 124-132.

Butler AE, Janson J, Bonner-Weir S, Ritzel R, Rizza RA \& Butler PC $2003 \beta$-cell deficit and increased beta-cell apoptosis in humans with type 2 diabetes. Diabetes 52 102-110.

Butler AE, Galasso R, Meier JJ, Basu R, Rizza RA \& Butler PC 2007 Modestly increased $\beta$ cell apoptosis but no increased $\beta$ cell replication in recent-onset type 1 diabetic patients who died of diabetic ketoacidosis. Diabetologia 50 2323-2331.

Castano L \& Eisenbarth GS 1990 Type-I diabetes: a chronic autoimmune disease of human, mouse, and rat. Annual Review of Immunology 8 647-679.

Chaudhary A, King WG, Mattaliano MD, Frost JA, Diaz B, Morrison DK, Cobb MH, Marshall MS \& Brugge JS 2000 Phosphatidylinositol 3-kinase regulates Raf1 through Pak phosphorylation of serine 338. Current Biology 10 551-554.

Cozar-Castellano I, Fiaschi-Taesch N, Bigatel TA, Takane KK, GarciaOcana A, Vasavada R \& Stewart AF 2006 Molecular control of cell cycle progression in the pancreatic beta cell. Endocrine Reviews 27 356-370.

Dai C, Chung IJ, Jiang S, Price JO \& Krantz SB 2003 Reduction of cell cycle progression in human erythroid progenitor cells treated with tumour necrosis factor alpha occurs with reduced CDK6 and is partially reversed by CDK6 transduction. British Journal of Haematology 121 919-927.

Delaney CA, Pavlovic D, Hoorens A, Pipeleers DG \& Eizirik DL 1997 Cytokines induce deoxyribonucleic acid strand breaks and apoptosis in human pancreatic islet cells. Endocrinology 138 2610-2614.

Dhillon AS, Meikle S, Yazici Z, Eulitz M \& Kolch W 2002 Regulation of Raf-1 activation and signalling by dephosphorylation. EMBO Journal 21 64-71.

Donath MY, Gross DJ, Cerasi E \& Kaiser N 1999 Hyperglycemiainduced beta-cell apoptosis in pancreatic islets of Psammomys obesus during development of diabetes. Diabetes 48 738-744.

Dor Y, Brown J, Martinez OI \& Melton DA 2004 Adult pancreatic $\beta$-cells are formed by self-duplication rather than stem-cell differentiation. Nature 429 41-46.

Dougherty MK, Muller J, Ritt DA, Zhou M, Zhou XZ, Copeland TD, Conrads TP, Veenstra TD, Lu KP \& Morrison DK 2005 Regulation of Raf-1 by direct feedback phosphorylation. Molecular Cell 17 215-224.

Dumaz N \& Marais R 2005 Integrating signals between cAMP and the RAS/RAF/MEK/ERK signalling pathways. Based on the anniversary prize of the Gesellschaft fur Biochemie und Molekularbiologie Lecture delivered on 5 July 2003 at the Special FEBS Meeting in Brussels. FEBS Journal 272 3491-3504.

Eizirik DL, Sandler S, Welsh N, Cetkovic-Cvrlje M, Nieman A, Geller DA, Pipeleers DG, Bendtzen K \& Hellerstrom C 1994 Cytokines suppress human islet function irrespective of their effects on nitric oxide generation. Journal of Clinical Investigation 93 1968-1974.

Fang Y \& Olah ME 2007 Cyclic AMP-dependent, protein kinase A-independent activation of extracellular signal-regulated kinase 1/2 following adenosine receptor stimulation in human umbilical vein endothelial cells: role of exchange protein activated by cAMP 1 (Epac1). Journal of Pharmacology and Experimental Therapeutics 322 1189-1200.

Finegood DT, Scaglia L \& Bonner-Weir S 1995 Dynamics of $\beta$-cell mass in the growing rat pancreas. Estimation with a simple mathematical model. Diabetes 44 249-256.

Hammar E, Parnaud G, Bosco D, Perriraz N, Maedler K, Donath M, Rouiller DG \& Halban PA 2004 Extracellular matrix protects pancreatic $\beta$-cells against apoptosis: role of short- and long-term signaling pathways. Diabetes 53 2034-2041. 
Holz GG 2004 Epac: a new cAMP-binding protein in support of glucagon-like peptide-1 receptor-mediated signal transduction in the pancreatic $\beta$-cell. Diabetes 53 5-13.

Hoorens A \& Pipeleers D 1999 Nicotinamide protects human beta cells against chemically-induced necrosis, but not against cytokineinduced apoptosis. Diabetologia $\mathbf{4 2}$ 55-59.

Johnson-Farley NN, Kertesy SB, Dubyak GR \& Cowen DS 2005 Enhanced activation of Akt and extracellular-regulated kinase pathways by simultaneous occupancy of Gq-coupled 5-HT2A receptors and Gs-coupled 5-HT7A receptors in PC12 cells. Journal of Neurochemistry 92 72-82.

Jonas JC, Sharma A, Hasenkamp W, Ilkova H, Patane G, Laybutt R, Bonner-Weir S \& Weir GC 1999 Chronic hyperglycemia triggers loss of pancreatic beta cell differentiation in an animal model of diabetes. Journal of Biological Chemistry 274 14112-14121.

Jones RG, Plas DR, Kubek S, Buzzai M, Mu J, Xu Y, Birnbaum MJ \& Thompson CB 2005 AMP-activated protein kinase induces a p53dependent metabolic checkpoint. Molecular Cell 18 283-293.

Larsen CM, Wadt KA, Juhl LF, Andersen HU, Karlsen AE, Su MS, Seedorf K, Shapiro L, Dinarello CA \& Mandrup-Poulsen T 1998 Interleukin-1 $\beta$-induced rat pancreatic islet nitric oxide synthesis requires both the p38 and extracellular signal-regulated kinase 1/2 mitogen-activated protein kinases. Journal of Biological Chemistry 273 15294-15300.

Laybutt R, Hasenkamp W, Groff A, Grey S, Jonas JC, Kaneto H, Sharma A, Bonner-Weir S \& Weir G $2001 \beta$-cell adaptation to hyperglycemia. Diabetes 50 S180-S181.

De Leon DD, Deng S, Madani R, Ahima RS, Drucker DJ \& Stoffers DA 2003 Role of endogenous glucagon-like peptide-1 in islet regeneration after partial pancreatectomy. Diabetes 52 365-371.

Li L, El-Kholy W, Rhodes CJ \& Brubaker PL 2005 Glucagon-like peptide-1 protects beta cells from cytokine-induced apoptosis and necrosis: role of protein kinase B. Diabetologia 48 1339-1349.

Lin SL, Johnson-Farley NN, Lubinsky DR \& Cowen DS 2003 Coupling of neuronal 5-HT7 receptors to activation of extracellular-regulated kinase through a protein kinase A-independent pathway that can utilize Epac. Journal of Neurochemistry 87 1076-1085.

Maedler K, Sergeev P, Ris F, Oberholzer J, Joller-Jemelka HI, Spinas GA, Kaiser N, Halban PA \& Donath MY 2002 Glucose-induced $\beta$ cell production of IL-1 $\beta$ contributes to glucotoxicity in human pancreatic islets. Journal of Clinical Investigation 110 851-860.

Maedler K, Storling J, Sturis J, Zuellig RA, Spinas GA, Arkhammar PO, Mandrup-Poulsen T \& Donath MY 2004 Glucose- and interleukin$1 \beta$-induced beta-cell apoptosis requires $\mathrm{Ca}^{2+}$ influx and extracellular signal-regulated kinase (ERK) $1 / 2$ activation and is prevented by a sulfonylurea receptor 1 /inwardly rectifying $\mathrm{K}^{+}$ channel 6.2 (SUR/Kir6.2) selective potassium channel opener in human islets. Diabetes 53 1706-1713.

McDaniel ML, Colca JR, Kotagal N \& Lacy PE 1983 A subcellular fractionation approach for studying insulin release mechanisms and calcium metabolism in islets of Langerhans. Methods in Enzymology 98 182-200.

Mellado-Gil JM \& Aguilar-Diosdado M 2004 High glucose potentiates cytokine- and streptozotocin-induced apoptosis of rat islet cells: effect on apoptosis-related genes. Journal of Endocrinology 183 155-162.

Mellado-Gil JM \& Aguilar-Diosdado M 2005 Assay for high glucosemediated islet cell sensitization to apoptosis induced by streptozotocin and cytokines. Biology Proceed Online 7 162-171.

Montanya E, Nacher V, Biarnes M \& Soler J 2000 Linear correlation between $\beta$-cell mass and body weight throughout the lifespan in Lewis rats: role of $\beta$-cell hyperplasia and hypertrophy. Diabetes 49 1341-1346.

Motoshima H, Goldstein BJ, Igata M \& Araki E 2006 AMPK and cell proliferation - AMPK as a therapeutic target for atherosclerosis and cancer. Journal of Physiology 574 63-71.
Ogawa N, List JF, Habener JF \& Maki T 2004 Cure of overt diabetes in NOD mice by transient treatment with anti-lymphocyte serum and exendin-4. Diabetes 53 1700-1705.

Park S, Dong X, Fisher TL, Dunn SL, Omer AK, Weir G \& White MF 2006 Exendin-4 promotes IRS2 signaling to mediate pancreatic $\beta$-cell growth and function. Journal of Biological Chemistry 281 1159-1168.

Pearson G, Robinson F, Beers Gibson T, Xu BE, Karandikar M, Berman K \& Cobb MH 2001 Mitogen-activated protein (MAP) kinase pathways: regulation and physiological functions. Endocrine Reviews 22 153-183.

Riboulet-Chavey A, Diraison F, Siew LK, Wong FS \& Rutter GA 2008 Inhibition of AMP-activated protein kinase protects pancreatic $\beta$-cells from cytokine-mediated apoptosis and CD8 + T-cell-induced cytotoxicity. Diabetes 57 415-423.

Richards SK, Parton LE, Leclerc I, Rutter GA \& Smith RM 2005 Overexpression of AMP-activated protein kinase impairs pancreatic $\beta$-cell function in vivo. Journal of Endocrinology 187 225-235.

Rommel C, Clarke BA, Zimmermann S, Nunez L, Rossman R, Reid K, Moelling K, Yancopoulos GD \& Glass DJ 1999 Differentiation stagespecific inhibition of the Raf-MEK-ERK pathway by Akt. Science $\mathbf{2 8 6}$ $1738-1741$.

Soltani N, Kumar M, Glinka Y, Prud'homme GJ \& Wang Q 2007 In vivo expression of GLP-1/IgG-Fc fusion protein enhances $\beta$-cell mass and protects against streptozotocin-induced diabetes. Gene Therapy 14 981-988.

SongJH, Wang CX, Song DK, Wang P, Shuaib A \& Hao C 2005 Interferon gamma induces neurite outgrowth by upregulation of p35 neuronspecific cyclin-dependent kinase 5 activator via activation ERK1/2 pathway. Journal of Biological Chemistry 280 12896-12901.

Sorenson RL \& Brelje TC 1997 Adaptation of islets of Langerhans to pregnancy: $\beta$-cell growth, enhanced insulin secretion and the role of lactogenic hormones. Hormone and Metabolic Research 29 301-307.

Tellez N, Montolio M, Biarnes M, Castano E, Soler J \& Montanya E 2005 Adenoviral overexpression of interleukin-1 receptor antagonist protein increases beta-cell replication in rat pancreatic islets. Gene Therapy 12 120-128.

Teta M, Long SY, Wartschow LM, Rankin MM \& Kushner JA 2005 Very slow turnover of $\beta$-cells in aged adult mice. Diabetes 54 2557-2567.

Trumper J, Ross D, Jahr H, Brendel MD, Goke R \& Horsch D 2005 The Rap-B-Raf signalling pathway is activated by glucose and glucagonlike peptide-1 in human islet cells. Diabetologia 48 1534-1540.

Vasavada RC, Gonzalez-Pertusa JA, Fujinaka Y, Fiaschi-Taesch N, CozarCastellano I \& Garcia-Ocañ A 2006 Growth factors and beta cell replication. International Journal of Biochemistry and Cell Biology $\mathbf{5 6}$ 2732-2743.

Wang Q \& Brubaker PL 2002 Glucagon-like peptide-1 treatment delays the onset of diabetes in 8 week-old db/db mice. Diabetologia 45 1263-1273.

Wang Q, Li L, Xu E, Wong V, Rhodes C \& Brubaker PL 2004 Glucagonlike peptide-1 regulates proliferation and apoptosis via activation of protein kinase B in pancreatic INS-1 $\beta$ cells. Diabetologia 47 478-487.

Xu G, Stoffers DA, Habener JF \& Bonner-Weir S 1999 Exendin-4 stimulates both $\beta$-cell replication and neogenesis, resulting in increased $\beta$-cell mass and improved glucose tolerance in diabetic rats. Diabetes 48 2270-2276.

Xu X, D'Hoker J, Stange G, Bonne S, De Leu N, Xiao X, Van De Casteele M, Mellitzer G, Ling Z, Pipeleers D et al. 2008 \& cells can be generated from endogenous progenitors in injured adult mouse pancreas. Cell 132 197-207.

Zimmermann S \& Moelling K 1999 Phosphorylation and regulation of Raf by Akt (protein kinase B). Science 286 1741-1744.

Received in final form 11 March 2008

Accepted 15 May 2008

Made available online as an Accepted Preprint 15 May 2008 